\title{
Enhanced Water Management of High-Surface-Density Ni Foam as Flow Field for PEM Fuel Cells
}

\author{
Yuzhen Xia, Zichen Wang, Jiedong Wang, Lili Cao, Yousheng Xu and Guilin Hu*
}

School of Mechanical and Energy Engineering, Zhejiang University of Science \& Technology, Hangzhou 310023, China

"E-mail: enehgl@163.com

Received: 2 November 2021 / Accepted: 13 December 2021 / Published: 5 January 2022

Ni foam with high surface density, has been proposed as an alternative flow field for PEM fuel cells, owing to large contact area, enhanced electron transport and low ohmic loss. The effect of pore diameter of $\mathrm{Ni}$ foam with high surface density above $1500 \mathrm{~g} \cdot \mathrm{m}^{-2}$ on physical parameters and cell performances was studied by polarization curves and EIS. Higher porosity, larger width of rib and higher flow field volume were obtained with pore diameter increasing. However, the cell performances of $\mathrm{Ni}$ foam were restricted, while larger $R_{\Omega}$ and $R_{c t}$ was depicted because of lower internal surface area. The water management $\mathrm{Ni}$ foam with optimal pore diameter of $450 \mu \mathrm{m}$ was studied at flood, moderate and dry state, respectively. As humidity temperature increasing from 20 to $50^{\circ} \mathrm{C}$, the power density increased, even at extremely flooding state. High-surface-density $\mathrm{Ni}$ foam behaved excellent mass transfer properties for reactant gas and liquid water in water management of PEM fuel cells.

Keywords: Ni foam, Surface density, Pore diameter, Water management

\section{FULL TEXT}

(C) 2022 The Authors. Published by ESG (www.electrochemsci.org). This article is an open access article distributed under the terms and conditions of the Creative Commons Attribution license (http://creativecommons.org/licenses/by/4.0/). 